\title{
The CONECOFOR Programme: general presentation, aims and co-ordination
}

\author{
Bruno PETRICCIONE and Enrico POMPEI
}

Ministry for Agriculture and Forestry Policy, National Forest Service, CONECOFOR Service, Via Carducci 5, I-00187 Roma, Italy e-mail: conecofor@corpoforestale.it

\begin{abstract}
Following EU Regulation no. 1091/94, the Ministry for Agriculture and Forestry Policy (National Forest Service) has since 1995 sponsored the "National Integrated Programme for Forest Ecosystems Monitoring" (CONECOFOR), implemented to study the effects of atmospheric pollution and climate change on forest ecosystems. The Programme also operates within the framework of the Geneva Convention on Trans-boundary air pollution (L.R.T.A.P. U.N.-E.C.E.), ratified by Italy in 1982, and of the Resolutions of the Ministerial Conferences on the protection of forests in Europe (Res. no. 1, Strasbourg, 1990, Res. H4, Helsinki, 1993). The Programme involves the development of the so-called Level I investigations, which have been in progress since 1987 on a European grid made up of $16 \times 16 \mathrm{~km}^{2}$. At present there are in Italy 265 monitoring plots distributed over the whole country, where annual assessments are made of the state of the tree crowns. At selected points within the same square, in 1995/6, pedological investigations were carried out and the chemical content of the leaves analysed. The Level II CONECOFOR Programme is currently based on 28 permanent plots in the framework of the International Co-operative Programme on Assessment and Monitoring of Air Pollution Effects on Forests; 11 areas are also classed as "biomonitoring sites", in the framework of the International Co-operative Programme on Integrated Monitoring of Air Pollution Effects on Ecosystems. Nine different researches have since 1996 been in progress in the permanent plots, involving the following analyses: geological and geomorphological (preliminary), vegetation (yearly), crown condition (yearly), chemical content of leaves (every 2 years), soil (every 10 years), variations in tree growth (every 5 years), atmospheric depositions (continuous), meteorological (continuous), atmospheric pollutants (continuous). Since 2000, surveys of soil solution (continuous), tree phenology (continuous) and ozone visible damage (yearly) have been added. Test phases of new surveys (biodiversity, biotic damage, etc.) are planned for 2002/3. The National Forestry Service (CONECOFOR Service) co-ordinates six participating research institutes, each of which is responsible for the analyses and monitoring activities. The permanent plots are selected according to the directive of EU Regulation no. 1091/94 so as to include the major forest ecosystems in Italy, and are distributed over the whole country. Each covers an area of 10-100 ha, within which two sample units of 2,500 $\mathrm{m}^{2}$ are designated. The main dominant species are Fagus sylvatica (10 areas), Picea abies (6), Quercus cerris (5), Quercus ilex (4), Quercus petraea (1) Quercus robur (1) and Abies alba (1). The first six years of the CONECOFOR Programme have resulted in a detailed, organic description of the main forest ecosystems in Italy. Implementation of the programme has meant that we are now in possession of a reasonably complete knowledge of the ecological characteristics of 17 different Italian forest communities ranging from the Alps to Sicily. The assessment and monitoring of forest health represent a key point for environmental policy-makers and for the management of environmental resources in the framework of sustainable development.
\end{abstract}

Key words: EU regulations, permanent plots, forest ecosystems, sustainable development, biodiversity, climate change

\section{INTRODUCTION}

Studies of forest condition on systematic national grids were started in Italy fifteen years ago, by the National Forest Service on behalf of the Ministry for Agriculture and Forestry Policy. Monitoring used to be based on descriptive parameters such as crown transparency scores; it now involves quantitative analyses of the processes occurring in forest ecosystems, regarded as well-organised biological systems which are highly reactive to environmental disturbances. This new ecological approach is the basis of the "National Integrated Programme for Forest Ecosystem Monitoring" (Programma Nazionale Integrato per il CONtrollo degli ECOsistemi FORestali, CONECOFOR), which was launched in 1995 under the aegis of the United Nations/Economic Commission for Europe (UN/ECE) and the European Union (EU) and which since 1997 has been fully functional; most of the analyses envisaged in the programme have been carried out. This paper provides information on how the Programme is run, on forest biocenosis characterisation and on the data collected so far.

Forest monitoring in Italy was initiated in the framework of several international activities:

- the International Co-operative Programme on the Assessment and Monitoring of Air Pollution Effects on Forests (ICP Forests) and the International Cooperative Programme on Integrated Monitoring of Air Pollution Effects (ICP-IM), which were established by the UN/ECE under its Convention on Long Range Trans-boundary Air Pollution (CLRTAP), ratified by Italy in 1982;

- the EU Scheme for the protection of forests against atmospheric pollution, started in 1986 by the first ad hoc Regulation n. 3528/86, followed by several implementation Regulations;

Paper prepared within the CONECOFOR programme, by the contract with the Ministry for Agriculture and Forestry Policy - National Forest Service, Italy. CONECOFOR is part of the Pan-European Level II Intensive Monitoring of Forest Ecosystem and is co-sponsored by the European Commission. 
- the Resolutions of the Ministerial Conferences on the protection of forests in Europe.(no. 1, Strasbourg, 1990, no. H4, Helsinki, 1993, No. L2, Lisbon, 1998).

From 1987, tree crown assessment, including the occurrence of a series of damaging events, was performed in Europe by the joint EU and UN/ECE systematic sample survey on forest condition ( $1^{\text {st }}$ level) according to a nominal $16 \times 16$ grid. More recently, a series of permanent plots for intensive forest monitoring $\left(2^{\text {nd }} l e v e l\right)$, has been established within the same programme to collect data on various indicators and processes in forest ecosystems.

Criteria for monitoring and the evaluation strategy of the $1^{\text {st }}$ and $2^{\text {nd }}$ level are laid down by a number of European Commission Regulations (EC Regulations nn. 3528/86, 2157/92, 1091/94, 690/95, 307/97, 1390/97, $1545 / 99,804 / 2002$, etc.). Action at international level is co-ordinated by the ICP Forests Programme Centre and the DG Environment of the European Commission. Technical details and surveying protocols are also included in international manuals based upon a general international agreement (UN/ECE 1998a, 1998b). International monitoring activity after 2002 (expiration date of EC Regulation n. 804/2002) will be probably based on a more global, more complex approach aimed at investigating ecosystem response (including biodiversity) to sources of disturbance such as air pollution, climate change and incorrect management.

Up to now, the results of monitoring have been documented in a wide range of reports (Kleemola \& Forsius 2000; UN/ECE \& EC 1997a, 1997b, 1997c, 2001a, 2001b) and constitute part of the scientific basis for the development of international protocols on air pollution abatement under CLRTAP of UN/ECE.

The Pan-European Intensive Programme of Forest Ecosystem Monitoring was started in 1994. The general aim of the Intensive Monitoring Programme is to contribute to a better understanding of the impact of air pollution and other factors on forest ecosystems. At present, the programme covers 866 plots in 30 participating countries (510 plots in the EU and 366 plots in non-EU countries). Due to its non-systematic character the intensive monitoring data set is not representative for Europe in the statistical sense, but it does give information on stress and effects on a European-wide scale. Some surveys are carried out on all plots (crown condition, soil and leaf chemistry, tree growth). Some of the plots are assessed for atmospheric deposition (499 plots), meteorology (202 plots), soil solution chemistry (243 plots), vegetation (632 plots) and remote sensing (155 plots). A total of 791 intensive monitoring plots have been set up. All the data and information on the methods applied have been validated and stored, for most of the plots ( $\mathrm{ca} 85 \%$ ), by the Forest Intensive Monitoring Co-ordinating Institute (FIMCI), a contractor of the European Commission.
In Italy, extensive monitoring on a European scale $\left(1^{\text {st }}\right.$ level $)$ on the international grid $(16 \times 16 \mathrm{~km})$, as well as intensive monitoring on a national network of permanent plots referred to as the CONECOFOR network $\left(2^{\text {nd }}\right.$ level), is directed and co-ordinated by the General Direction of Forestry, Mountain and Water Resources (National Forest Service, CONECOFOR Service) of the Ministry for Agriculture and Forestry Policy.

The systematic sample grid $16 \times 16 \mathrm{~km}\left(1^{\text {st }}\right.$ level $)$ is representative of the total forest area, which covers almost $8,675,100$ ha. Of this area, 6,147,000 ha $(70,9 \%)$ are semi-natural high forests, 2,239,200 ha $(25,8 \%)$ are macchia and degraded stands and 288,900 ha $(3,3 \%)$ are productive artificial stands. Of the $8,675,100$ ha of the total forest area (28.8\% of the total area of the country), $79.9 \%$ is under broadleaves (macchia included), 20,1\% under conifers. From 1989 to 1995 , crown condition was monitored in 220 observation plots, with a total of 5,614 trees evaluated. The last few years have seen a decrease in observation plots and trees, with the loss of several wood stands due to forest fires and felling. Currently (in the year 2001), there is a total of 265 observation plots and 7,351 evaluated trees. From 1985 to 1995 crown condition assessment was also carried out on a $3 \times 3 \mathrm{~km}$ plot grid (National Forest Inventory - "Indagine Nazionale sul Deperimento delle Foreste", INDEFO) in almost 9.600 sites covering a total forest area of $6,733,800$ ha. Since there was no significant difference between the INDEFO data and those of the 1st Level, the INDEFO assessment was suspended in 1996, while more detailed observations are now being carried out on the 1 st level grid.

In 1995 and 1996 soil and foliar surveys were made in 89 and 57 plots respectively. Results and data were submitted to the Forest Soil Co-ordinating Centre (FSCC) in Gent (Belgium) and to the Forest Foliar Coordinating Centre (FFCC) in Wien (Austria), which coordinate these analyses at international level.

Monitoring is performed under the responsibility of the Ministry for Agriculture and Forestry Policy (National Forest Service, CONECOFOR Service), which is in charge of validation, and submits national data and results to the European Commission and to the ICP Forest and ICP IM. The Ministry also collaborates with the research laboratories of the Department of Forest Environment and Resources of the Tuscia University (Viterbo) and of the Department of Botany of the University of Florence, which are responsible for scientific co-ordination, data collection, the training of personnel from National and/or Regional Forest Services involved in field work, and the control and inspection of the surveys.

Defoliation and discoloration are the main parameters evaluated in crown condition assessment. Of the species affected by defoliation, Pinus spp., Abies alba, Fagus sylvatica and Castanea sativa showed the highest values of crown transparency. As regards soil analysis, 


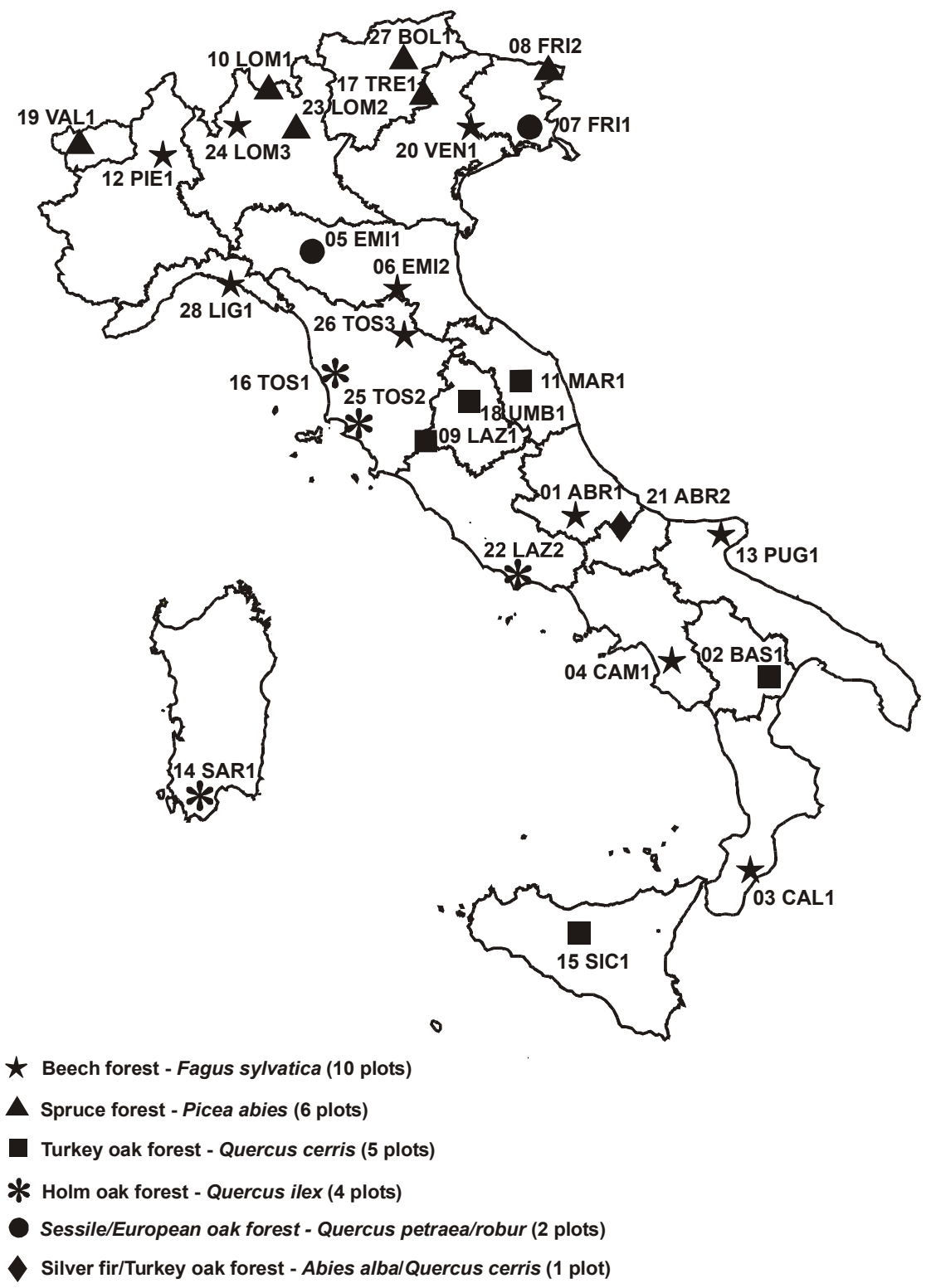

Fig. 1. Geographical location of the National Network CONECOFOR permanent plots.

the $\mathrm{C} / \mathrm{N}$ ratio seemed to decrease regularly with depth, ranging from 30.8 to 15.6 in the organic layer and from 30.2 to 8.0 in the lowest mineral layer $(10-20 \mathrm{~cm})$; the highest values were found in Picea abies plots. Acidity values ranged from $\mathrm{pH} 3.0$ to 7.2; the lowest values were found in Picea abies plots. As regards leaf analyses, data referring to a single species in different sites did not show any significant results.

\section{THE CONECOFOR PROGRAMME}

\subsection{Introduction}

The National Programme for Forest Ecosystem Monitoring CONECOFOR (Petriccione \& Isopi 1996, Allavena et al. 2001) was launched in 1995 within the framework of the $2^{\text {nd }}$ level forest monitoring (EC
Regulation n. 1091/94) and to answer new questions arising in this field. Formerly structured as a national network including 20 permanent plots, the CONECOFOR Programme currently covers 28 plots (Fig. 1, Tabb 1, 2). Since 1997, ten of them have also been included in the European Network for Integrated Monitoring of Ecosystems established under the International Co-operative Programme on Integrated Monitoring of Air Pollution Effects (ICP-IM).

Permanent plots (Tab. 1), distributed over all the national territory, are representative of the major forest biocenoses (Fagus sylvatica - beech woods: 10 plots; Quercus cerris - turkey oak woods: 5 plots, Picea abies - spruce woods: 6 plots; Quercus ilex - holm oak woods: 4 plots; Quercus robur - sessile oak (1 plot) Quercus petraea European oak woods: 1 plot; Abies alba - silver fur: 1 plot). 
Tab. 1. Codes, names, main geographical and lithological characteristics and tree dominant species in the CONECOFOR plots.

\begin{tabular}{|c|c|c|c|c|c|c|}
\hline Code & Name & Lat. & Long. & Altitude (m a.s.1.) & Lithological substrate & Dominant species \\
\hline 01-ABR1 & Selva Piana & $41^{\circ} 50^{\prime} 51^{\prime \prime}$ & $13^{\circ} 35^{\prime} 23^{\prime \prime}$ & 1500 & Limestone & Fagus sylvatica \\
\hline 02-BAS1 & Monte Grosso & $40^{\circ} 36^{\prime} 38^{\prime \prime}$ & $15^{\circ} 52^{\prime} 25^{\prime \prime}$ & 1125 & Sandstone flisch & Quercus cerris \\
\hline 03-CAL1 & Piano Limina & $38^{\circ} 25^{\prime} 38^{\prime \prime}$ & $16^{\circ} 10^{\prime} 47^{\prime \prime}$ & 1100 & Granite & Fagus sylvatica \\
\hline 04-CAM1 & Serra Nuda & $40^{\circ} 25^{\prime} 58^{\prime \prime}$ & $15^{\circ} 26^{\prime} 10^{\prime \prime}$ & 1175 & Limestone & Fagus sylvatica \\
\hline 05-EMI1 & Carrega & $44^{\circ} 43^{\prime} 06^{\prime \prime}$ & $10^{\circ} 12^{\prime} 13^{\prime \prime}$ & 200 & Ancient alluvium & Quercus petraea, Quercus cerris \\
\hline 06-EMI2 & Brasimone & $44^{\circ} 06^{\prime} 31^{\prime \prime}$ & $11^{\circ} 07^{\prime} 00^{\prime \prime}$ & 975 & Sandstone & Fagus sylvatica \\
\hline 07-FRI1 & Bosco Boscat & $45^{\circ} 49^{\prime} 58^{\prime \prime}$ & $13^{\circ} 10^{\prime} 04^{\prime \prime}$ & 6 & Recent alluvium & Carpinus betulus, Quercus robur \\
\hline 08-FRI2 & Tarvisio & $46^{\circ} 29^{\prime} 28^{\prime \prime}$ & $13^{\circ} 35^{\prime} 36^{\prime \prime}$ & 820 & Phyllites & Picea abies \\
\hline 09-LAZ1 & Monte Rufeno & $42^{\circ} 49^{\prime} 50^{\prime \prime}$ & $11^{\circ} 54^{\prime} 10^{\prime \prime}$ & 690 & Sandstone flisch & Quercus cerris \\
\hline 10-LOM1 & Val Masino & $46^{\circ} 14^{\prime} 16^{\prime \prime}$ & $09^{\circ} 33^{\prime} 16^{\prime \prime}$ & 1190 & Granite & Picea abies \\
\hline 11-MAR1 & Roti & $43^{\circ} 17^{\prime} 38^{\prime \prime}$ & $13^{\circ} 04^{\prime} 24^{\prime \prime}$ & 775 & Limestone & Quercus cerris \\
\hline 12-PIE1 & Val Sessera & $45^{\circ} 40^{\prime} 55^{\prime \prime}$ & $08^{\circ} 04^{\prime} 02^{\prime \prime}$ & 1150 & Mica schist & Fagus sylvatica \\
\hline 13-PUG1 & Foresta Umbra & $41^{\circ} 49^{\prime} 10^{\prime \prime}$ & $15^{\circ} 59^{\prime} 00^{\prime \prime}$ & 800 & Limestone & Fagus sylvatica \\
\hline 14-SAR1 & Marganai & $39^{\circ} 20^{\prime} 56^{\prime \prime}$ & $08^{\circ} 34^{\prime} 08^{\prime \prime}$ & 700 & Sandstone & Quercus ilex \\
\hline 15-SIC1 & Ficuzza & $37^{\circ} 54^{\prime} 32^{\prime \prime}$ & $13^{\circ} 24^{\prime} 15^{\prime \prime}$ & 940 & Sandstone & Quercus cerris \\
\hline 16-TOS1 & Colognole & $43^{\circ} 30^{\prime} 34^{\prime \prime}$ & $10^{\circ} 26^{\prime} 19^{\prime \prime}$ & 150 & Gabbro & Quercus ilex \\
\hline 17-TRE1 & Passo Lavazè & $46^{\circ} 21^{\prime} 37^{\prime \prime}$ & $11^{\circ} 29^{\prime} 42^{\prime \prime}$ & 1775 & Granite & Picea abies \\
\hline 18-UMB1 & Pietralunga & $43^{\circ} 27^{\prime} 57^{\prime \prime}$ & $12^{\circ} 27^{\prime} 57^{\prime \prime}$ & 725 & Sandstone flisch & Quercus cerris \\
\hline 19-VAL1 & La Thuile & $45^{\circ} 43^{\prime} 26^{\prime \prime}$ & $06^{\circ} 55^{\prime} 55^{\prime \prime}$ & 1740 & Gneiss, mica schist & Picea abies \\
\hline 20-VEN1 & Pian di Cansiglio & $46^{\circ} 03^{\prime} 26^{\prime \prime}$ & $12^{\circ} 01^{\prime} 56^{\prime \prime}$ & 1100 & Limestone & Fagus sylvatica \\
\hline 21-ABR2 & Rosello & $41^{\circ} 54^{\prime} 09^{\prime \prime}$ & $14^{\circ} 21^{\prime} 00^{\prime \prime}$ & 960 & Sandstone, limestone & Abies alba, Quercus cerris \\
\hline 22-LAZ2 & Monte Circeo & $41^{\circ} 14^{\prime} 14^{\prime \prime}$ & $12^{\circ} 37^{\prime} 40^{\prime \prime}$ & 190 & Limestone & Quercus ilex \\
\hline 23-LOM2 & Giovetto & $45^{\circ} 57^{\prime} 26^{\prime \prime}$ & $10^{\circ} 07^{\prime} 53^{\prime \prime}$ & 1260 & Shales, limestone & Picea abies \\
\hline 24-LOM3 & Valsassina & $45^{\circ} 54^{\prime} 41^{\prime \prime}$ & $09^{\circ} 30^{\prime} 17^{\prime \prime}$ & 1250 & Sandstone, limestone & Fagus sylvatica \\
\hline 25-TOS2 & Cala Violina & $42^{\circ} 52^{\prime} 12^{\prime \prime}$ & $10^{\circ} 46^{\prime} 34^{\prime \prime}$ & 30 & Sandstone & Quercus ilex \\
\hline 26-TOS3 & Vallombrosa & $43^{\circ} 44^{\prime} 18^{\prime \prime}$ & $11^{\circ} 34^{\prime} 22^{\prime \prime}$ & 1170 & Sandstone & Fagus sylvatica \\
\hline 27-BOL1 & Renon & $46^{\circ} 35^{\prime} 16^{\prime \prime}$ & $11^{\circ} 26^{\prime} 04^{\prime \prime}$ & 1740 & Morain, quartz porphyry & Picea abies \\
\hline 28-LIG1 & Monte Zatta & $44^{\circ} 24^{\prime} 10^{\prime \prime}$ & $09^{\circ} 27^{\prime} 30^{\prime \prime}$ & 1290 & Sandstone & Fagus sylvatica \\
\hline
\end{tabular}

Tab. 2. Ownership, system of protection, managing agencies of the CONECOFOR plots; codes of the sites participating in the ICP Integrated Monitoring network. Acronyms: CFS: Corpo Forestale dello Stato; CR-ENEA: Centro Ricerche Ente Nazionale Energie Alternative.

\begin{tabular}{|c|c|c|c|c|c|}
\hline Code & Name & Land ownership & System of protection & Managing agency & ICP-IM code \\
\hline 01-ABR1 & Selva Piana & Municipal & National Park & CFS & IT05 \\
\hline 02-BAS1 & Monte Grosso & Municipal & No protection & CFS & - \\
\hline 03-CAL1 & Piano Limina & Municipal & No protection & CFS & IT06 \\
\hline 04-CAM1 & Serra Nuda & Municipal & National Park & CFS & - \\
\hline 05-EMI1 & Carrega & Regional Park & Regional Park & Regional Park & IT07 \\
\hline 06-EMI2 & Brasimone & ENEA & Various & CR-ENEA & IT08 \\
\hline 07-FRI1 & Bosco Boscat & Municipal & No protection & CFS & - \\
\hline 08-FRI2 & Tarvisio & State & Pubblic Forest & CFS & - \\
\hline 09-LAZ1 & Monte Rufeno & Regional & Regional Park & CFS & IT09 \\
\hline 10-LOM1 & Val Masino & Regional & Public Forest & Region & IT10 \\
\hline 11-MAR1 & Roti & Regional & Public Forest & CFS & IT11 \\
\hline 12-PIE1 & Val Sessera & Regional & Public Forest & Region & - \\
\hline 13-PUG1 & Foresta Umbra & State & National Park & CFS & - \\
\hline 14-SAR1 & Marganai & Regional & Public Forest & Region & - \\
\hline 15-SIC1 & Ficuzza & Regional & Public Forest & Region & - \\
\hline 16-TOS1 & Colognole & Municipal & No protection & Province & IT12 \\
\hline 17-TRE1 & Passo Lavazè & Municipal & No protection & Province & IT03 \\
\hline 18-UMB1 & Pietralunga & Regional & Public Forest & CFS & - \\
\hline 19-VAL1 & La Thuile & Municipal & No protection & Region & IT13 \\
\hline 20-VEN1 & Pian di Cansiglio & State & Public Forest & CFS & - \\
\hline 21-ABR2 & Rosello & Municipal & Regional Park & Regional Reserve & - \\
\hline 22-LAZ2 & Monte Circeo & Municipal & National Park & CFS & - \\
\hline 23-LOM2 & Giovetto & Municipal & Regional Park & Region & - \\
\hline 24-LOM3 & Valsassina & Municipal & No protection & Region & - \\
\hline 25-TOS2 & Cala Violina & Municipal & Various & Region & - \\
\hline 26-TOS3 & Vallombrosa & State & Public Forest & Region & - \\
\hline 27-BOL1 & Renon & Private & Various & Province & IT01 \\
\hline 28-LIG1 & Monte Zatta & Regional & Regional Park & Region & - \\
\hline
\end{tabular}


Analyses include crown condition assessment (yearly), chemical content of soil (every 10 years) and leaves (every 2 years), deposition and air pollutants (continuous), tree growth assessment (every 5 years), climate (continuous) and vegetation assessment (yearly). Since 2000, surveys of soil solution (continuous), tree phenology (continuous) and ozone visible damage (yearly) have been added. Test phases of new surveys (biodiversity, biotic damage, etc.) are planned for $2002 / 3$.

With the establishment of a national network, all the investigations on forest condition in Italy have been unified in one project. In this respect the CONECOFOR Programme is both an extension and integration of projects already existing at regional or national level, co-financed by the European Commission under the same Regulations.

Field work is carried out on each plot by staff working for decentralised structures of the National Forest Service, by Regional Administrations or by scientists from local laboratories, following survey-specific National manuals. Inter-calibration courses and updating meetings are organised yearly to make field work easier and improve data quality.

\subsection{Organising structure}

The CONECOFOR Programme is included in the activities on forest monitoring co-ordinated at international level by the European Commission and by the Co-ordinating Centre of ICP Forests and ICP IM. The European Commission is also advised by a Scientific Advisory Group (SAG) of experts in forestry disciplines from the countries participating in international programmes on forest monitoring. The SAG is responsible for setting up monitoring guidelines and for evaluating the activities proposed by the Groups of Experts, as well as for taking decisions on future strategy.

The Forest Intensive Monitoring Co-ordinating Institute (FIMCI) is the advisory institution responsible for international data management. Data and results submitted by countries at the end of every year are stored in an international data bank and processed by FIMCI. In the framework of the European Commission, Expert Panels or Working Groups (EP/WG) have been also created to work on the analytical activity prescribed by EC Regulations for the $2^{\text {nd }}$ level. EP/WG include experts in charge of analyses at National level. Expert Panels and Working Groups are currently involved in work on deposition (including air pollutant analysis), crown condition, meteorology, ground vegetation, phenology, tree growth, soil, foliar analysis, biodiversity, ozone and remote sensing. At a national level, National Focal Centres (NFCs) have been established to co-ordinate activities relating to forest monitoring programmes. NFCs are also responsible for submitting programmes to the European Commission at the end of each year for financial support, and for validating tech- nical and financial achievement. In Italy the NFC is represented by the General Direction for Forestry, Mountain and Water Resources (National Forest Service CONECOFOR Service) of the Ministry for Agriculture and Forestry Policy, where a scientific and administrative staff is employed full time. The NFC underwrites contracts annually with National research Institutes responsible for the scientific co-ordination of the surveys, data collection, analysis of samples and evaluation at National level.

Financial resources for the National Programme, including $1^{\text {st }}$ and $2^{\text {nd }}$ level ( $c a 1,000,000 €$ per year), are guaranteed by a contribution from the EC of $50 \%$.

A tutor with responsibility for plot management and fieldwork (including sampling of water, leaves and air pollutants), is appointed for each permanent plot. Tutors are employed by the National Forest Service, or Local Administrations if plots are located on land belonging to Local Authorities.

\subsection{Network}

Most of the 28 plots are located on hill or mountain slopes at altitudes between 500 and $1500 \mathrm{~m}$ (Tab. 1); only 3 plots are on alluvial plains (EMI1 e FRI1) or near the coast (TOS2). The lithological substrate is mostly sedimentary, with only a few plots on alluvial, metamorphic or volcanic soils. Most of the soils are Cambisoils and Luvisoils and are therefore acid; the only exception is UMB1, in which the soil appears to be neutral.

Differences in altitude and latitude are reflected in the diverse climatic conditions of the plots. Most of them have a climate characterised by annual precipitation ranging from 1000 to $1500 \mathrm{~mm}$ and temperatures ranging from 10 to $12^{\circ} \mathrm{C}$, but two (FRI1 and TOS2) are very dry with $500-650 \mathrm{~mm}$ of precipitation, while conditions at EMI2 and VEN1 are very wet, with precipitation between 1800 and $1900 \mathrm{~mm}$.

The plots are distributed over two bio-climatic regions: Central European (12) and Mediterranean (16), and four altitude belts from Mediterranean to Boreal; most of the plots, however, are located in intermediate belts (Subatlantic, 14 plots and Central European, 6).

The plots are mostly the property of local authorities, with the State owning only four of them (Tab. 2). 21 plots are in protected areas, while, for 7 of them, the only protection is that implicit in the CONECOFOR Programme.

The average age of the dominant trees varies widely among the plots; the number of trees per plot is directly correlated to species composition and biocenosis structure.

In 1994, 40 permanent plots were visited to select 20, on the basis of criteria laid down in EC Regulation n. 1091/94. Some priorities established at a National level were focused on particularly, such as the inclusion of the plot in a pre-existing network, rates of ecological 


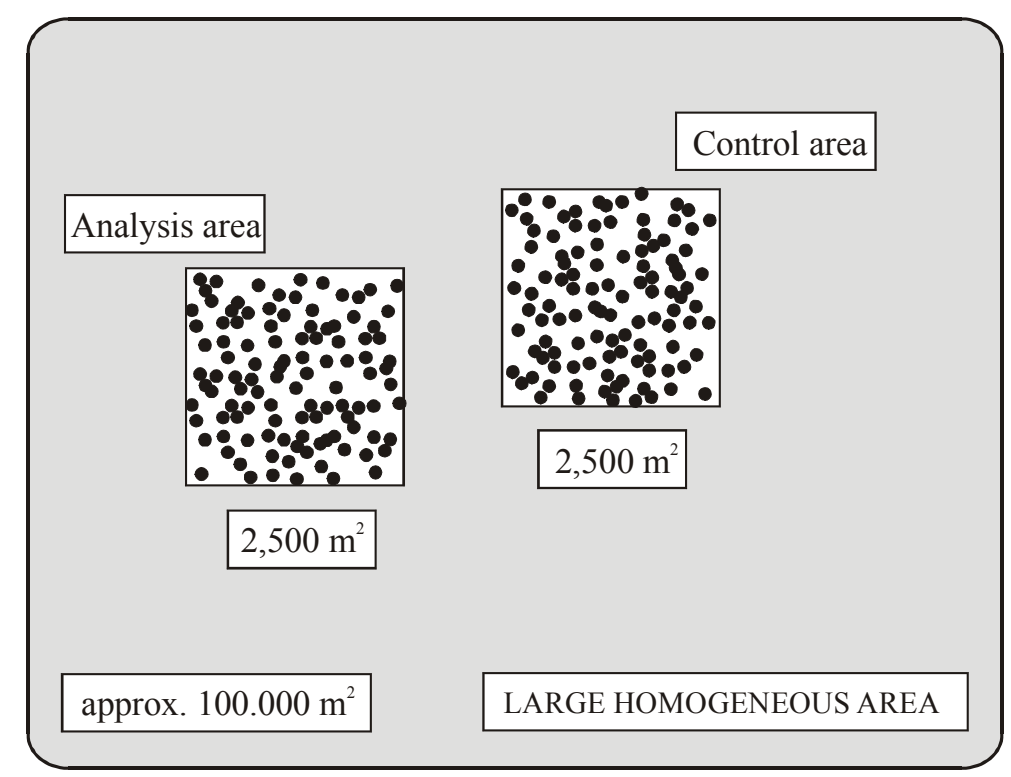

Fig. 2. Diagram of a typical CONECOFOR permanent plot.

uniformity, Regional or National representation, land owner, land protection type, site location (far from local pollution sources) and availability of local support teams. The same criteria were followed in the extension of the CONECOFOR network to 26 and 28 plots in 1998 and 2000/1.

The establishment procedure of the CONECOFOR Network in 1995 was the following:

- selection of a uniform plot of land with a minimum area of $100,000 \mathrm{~m}^{2}$;

- establishment within each plot of two squared areas of $2500 \mathrm{~m}^{2}$ (analysis and control areas) (Figs 2, 3);

- selection of an open field site;

- establishment of $2510 \times 10$ subplots within the analysis area;

- identification in the field and on the map of 5 sites for soil sampling within the analysis area;

- identification in the field and on the map of the 5 trees per dominant species for leaf sampling within analysis area;

- selection of trees for crown condition assessment within analysis area;

- numbering of all trees in the analysis area in the field and on the 1:250 scale map (example in Fig. 4);

- micro-topographic sampling of analysis area;

- fencing off of analysis and control areas (if necessary to prevent damage to trees and instruments deployed).

A permanent plot is made up of two contiguous $2500 \mathrm{~m}^{2}$ areas, one for analyses and the other as control; the latter is used only to give data on vegetation as an indication of biocenosis condition. An outline of a typical analysis area including buffer zone, service areas, fence, fenced off meteorological station, and bulk/litter/stem-flow collectors is shown in figure 2 .
Some general procedures have been adopted to reduce the impact of sampling activities. For each permanent plot, 4 categories of sampling areas are defined according to the degree of protection used (analysis area, control area, buffer zone and service area). Furthermore, in the course of field work, in particular during deposition surveys, the personnel are careful to empty stem flow collectors outside the analysis area, to limit the number of people in the analysis area during surveying activity and to avoid trampling on subplots for vegetation assessment.

\subsection{Analyses}

Analyses are carried out in permanent plots under the responsibility and scientific co-ordination of research Institutes and University Departments (see above). The methods used and the frequency of each analysis are reported in Regulations of the European Commission regarding 2nd level monitoring activities, in ICP-Forests and ICP-IM manuals and in national manuals on deposition, ground vegetation and tree crowns. Two levels of intensity were defined within the network according to the number of analyses set up per plot.

\subsubsection{Ground vegetation}

The main objective of the assessment of ground vegetation is to determine the changes in vegetation due to natural dynamics and macro-disturbance factors (air pollution, climate changes, etc.). Vegetation has been assessed in all CONECOFOR plots since 1996/7. Assessment is planned every three years (18 plots) or annually (10 plots), according to two different approaches: (1) phytosociological (plant community level) and (2) dynamic (population level). In the first approach, the 


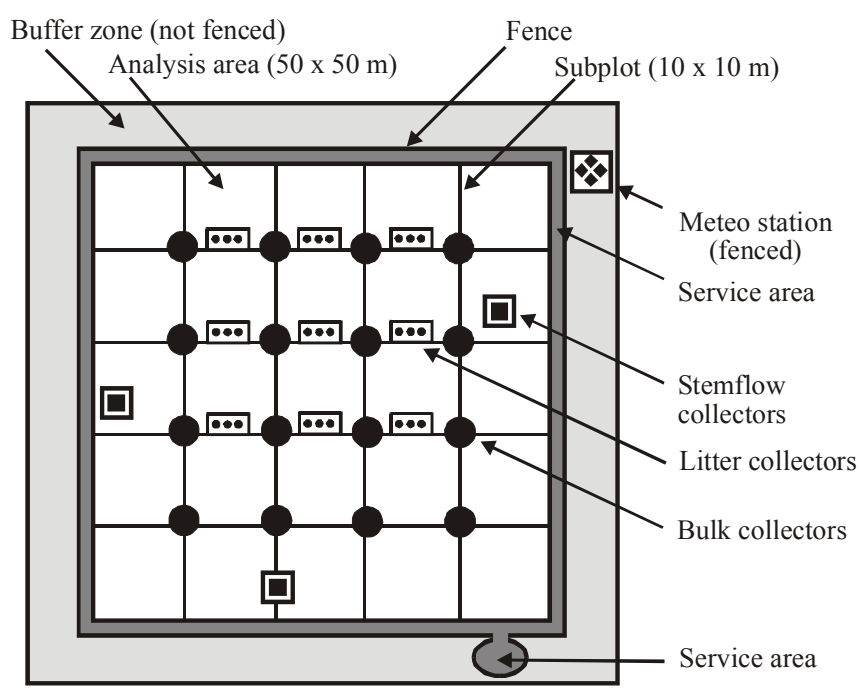

Fig. 3. Diagram of a typical analysis area within the CONECOFOR plots.

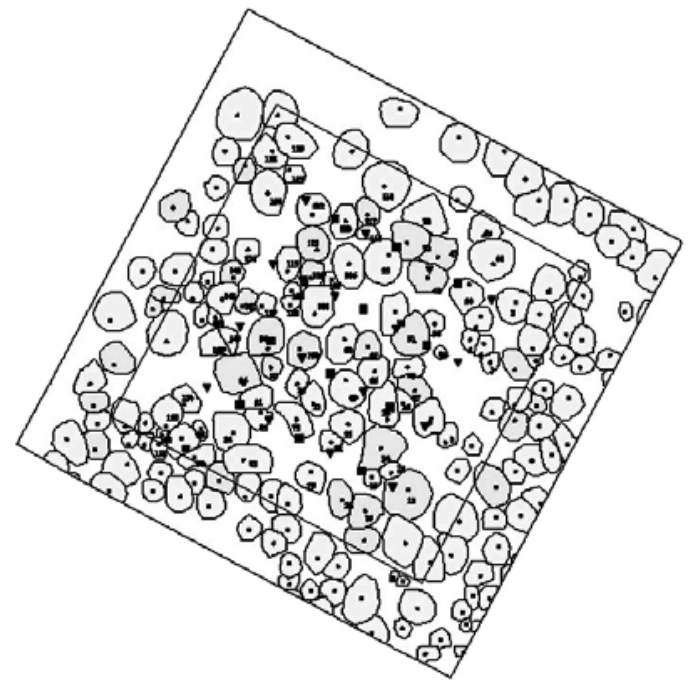

Fig. 4. Permanent plot VAL1: crown map derived by aerophotographs.

Braun-Blanquet data collection method (coverage scale for each species) is applied on the analysis area and on the large surrounding area, divided into 24 sample units of $100 \mathrm{~m}^{2}$. The second approach is based on 100 smaller sample units $\left(0,25 \mathrm{~m}^{2}\right)$, where species coverage is studied in greater detail; a detailed map of plant populations (synusies) or functional individuals occurring in the analysis area is also made. A systematic and syntaxonomical outline of plant communities represented in the CONECOFOR permanent plots is reported in table. 2 .

\subsubsection{Crown conditions}

The tree condition survey is aimed at identifying the status of the forest trees at the monitoring plots and any changes they undergo. The survey is based on a visual assessment of 30 trees per plot, each tree being scored according to a series of indicators. 17 plots were surveyed in 1996, 19 in 1997, 20 in 1998, 24 in 1999, and 25 in 2000/1. As an example of the results, Fagus sylvatica plots display a marked increase in transparency between 1996 and 1997, but not between 1997 and 1998. On the other hand, Quercus cerris plots have shown considerable changes since 1996. However, in both cases most of the observed changes fall within the accuracy limits of the survey method.

\subsubsection{Soil analysis}

The aim of this research is to obtain basic information on the chemical condition of soils and the properties that determine their vulnerability to air pollution. The main information required is the ability of soils to resist atmospheric depositions, specifically acidification, 
nutritional imbalances and contamination by heavy metals. The analyses were performed in 1995/6 using the methods of the Programme Co-ordinating Centre (1994). 20 sites distributed all over the country were studied. The first results reveal the following general characteristics of the soils: they have a rather low organic carbon content, demonstrate a good capacity of resistance to acidification, and do not show much evidence of nutritional imbalance due to atmospheric depositions.

\subsubsection{Chemical content of leaves}

The chemical content of leaves and needles was analysed to investigate the nutritional conditions of the trees. An imbalance of mineral content could be one of the general causes of the decline of forest ecosystems. Samples from 5 different trees representative of ecosystem health conditions were collected in the permanent plots. All the plots were sampled in 1995, 1997, 1999 and 2001, during autumn-winter for evergreens and August-September for deciduous species, before the leaves began to turn yellow.

\subsubsection{Tree growth}

Tree growth was assessed in 1996 and 1999 by surveying basic dendrometric variables, tree species composition and individual social rank. By using this approach it was possible to elaborate a complete frame of references for each plot, the analysis of the standing crop being feasible at tree, social layer and tree population level. Past growth was evaluated and any changes highlighted by annual ring analysis. The estimate of annual litter production and of the Leaf Area Index (LAI) provided further elements with which to judge stand productivity in each forest type observed.

\subsubsection{Deposition analysis}

Atmospheric deposition chemistry has been measured in 16 permanent plots of the CONECOFOR network since 1997. Sampling methods and the mailing and treatment of samples are in strict agreement with those used in the European network. Three laboratories are responsible for the measurements. Analytical quality controls include inter-comparison exercises as well as criteria for data validation based on the ionic balance and the comparison between measured and calculated conductivity.

\subsubsection{Meteorological monitoring}

Climate research is very important in studying and classifying areas and is the starting point for all the other researches in the CONECOFOR Programme. Data collected in 16 plots, with 24 stations located in the plot and in open field, have since 1997 been stored in a database comprising two sections, describing the geographical characteristics of the areas, measured parameters and their elaboration, and containing acquired measurements for the observed parameters. We used three models (De Martonne, Gaussen, Thornthwaite) to try and classify four areas for 1998, to characterise the climate through some indices.

\subsubsection{Atmospheric pollutant}

Following the appearance of forest decline phenomena, air pollution in remote areas has received increasing attention. Information about air pollution in forest areas is often scarce and fragmentary. Passive samplers are monitoring devices based on the diffusion of air pollutants onto an absorbing medium and can provide basic exposure information regarding air pollution. They are inexpensive and do not require electricity or highly skilled personnel on site. Since 1996, ozone passive samplers have been exposed at all the plots in the CONECOFOR network. Tests performed on the adopted sampler type show a statistically high correlation between the samplers and continuous measurements.

Monitoring results reveal high ozone concentrations (weekly averages) in several areas, especially in Southern Italy, and show that concentrations are clearly influenced by weather conditions. Correlation between monitoring sites suggests a regional occurrence of ozone episodes.

\subsubsection{Remote sensing}

Colour InfraRed (CIR) aerial photographs are a well-tested tool for collecting information about the characteristics and conditions of health of forest stands and trees. High scale (1:5.000) CIR air photographs were taken of 20 plots in the CONECOFOR network during 1996 and 1997. The same approach was adopted in other European countries (e.g. Austria, Ireland and Germany), working to a programme prepared by the EU Working Group on remote sensing and forest health assessment. Maps describing the plots and their representativness as regards land use, tree species, natural age and crown condition were developed photogrammetrically. Air photographs were subsequently interpreted to define crown conditions (defoliation and yellowing) in the plot and in the buffer zone. Measurements of canopy surface were carried out on a regular grid $(1 \times 1 \mathrm{~m})$, and the data collected were processed to develop a digital canopy model and to show canopy illumination and roughness.

\section{CONCLUSIONS}

Forests are of exceptional value and great care should be devoted to saving their health. If they are to be safeguarded and their ecological efficiency maintained, it is essential to know how, and how quickly, forest health can be endangered, whether by "traditional" (pests, pathogens, weather conditions) or "new" 
factors (air pollution, climate changes), or a combination of both.

The first six years of the CONECOFOR Programme have resulted in a detailed, organic description of the main forest ecosystems in Italy. The implementation of the programme has meant that we are now in possession of a reasonably complete knowledge of the ecological characteristics of 17 different Italian forest communities, ranging from the Alps to Sicily. They have been studied in all their most important components such as soil, vegetation, macro- and micro-climate and atmospheric pollutants. Information has been collected on the health of forest populations and their structure and functioning.

After the first four years of the programme, the data collected were subjected to an evaluation, the first attempt to provide a concrete example of the Integrated and Combined evaluation system (Ferretti 2000). In this context, the potential for co-occurrence of sensitive soil conditions and high deposition of acidifying compounds and nitrogen was examined. Similarly, ozone levels and indices of drought stress were considered. Tree condition, ground vegetation and ozone data collected at beech sites were jointly examined to show how the status and change analysis could work. Results show that there is the potential for exceedance of critical acidity loads in the most sensitive forest ecosystems in Italy. Mean weekly ozone values were rather high; however, there is evidence that ozone uptake may be affected by different meteorological conditions in different years. The status and changes of five beech sites were found to fluctuate around a mean, with two sites being far from the mean distance in 1999. An integrated and combined elaboration of the data generated by the permanent plots is now in progress, with emphasis on the role of ozone: the results will be published by the end of 2002 .

This is an important contribution to the pool of information which has resulted, and will result over the next few years, from all the programmes monitoring European forests. This information will extend our knowledge of forests (in particular as regards relationships of cause and effect between various interacting factors); it should also encourage debate on development quality, and on the economic and political decisions to be implemented to ensure a model of development which is sustainable and compatible with the conservation of the natural environment.

\section{REFERENCES}

Allavena, S., R. Isopi, B. Petriccione \& E. Pompei. 2001. Programma Nazionale Integrato per il Controllo degli Ecosistemi Forestali. Secondo rapporto. 2000. Ministero per le Politiche Agricole e Forestali (Roma): 167 pp.

Kleemola, S. \& M. Forsius (Eds). 2000. 9th Annual Report 2000. UN/ECE ICP Integrated Monitoring. The Finnish Environment, 427. Finnish Environment Institute. Helsinki.

Ferretti, M. (Ed.). 2000. Integrated and Combined (I\&C) evaluation of intensive monitoring of forest ecosystems in Italy. Concepts, methods and First Results. Annali Istituto Sperimentale per la Selvicoltura, Special Issue 1999 (Ârezzo), 30: $156 \mathrm{p}$.

Petriccione, B. \& R. Isopi. 1996. The Italian National Integrated Network for Forest Ecosystems Monitoring (CONECOFOR). In: Proceedings of the 17th International Meeting for Specialists in Air Pollution Effects on Forest Ecosystems. Sept. 14-19, 1996, Florence, Italy).

UN/ECE 1998a. Convention On Long-Range Transboundary Air Pollution. International Co-operative Programme on Assessment and Monitoring of Air Pollution Effects on Forests. Manual on methods and criteria for harmonised sampling, assessment, monitoring and analysis of the effects of air pollution on forests. BFH, Hamburg.

UN/ECE 1998b. Convention On Long-Range Transboundary Air Pollution. International Co-operative Programme on Integrated Monitoring of Air Pollution Effects on Ecosystems. Manual for integrated monitoring. ICP IM Programme Centre, Helsinki.

UN/ECE \& EC 1997a. Forest Foliar Condition in Europe. Results of a large scale foliar chemistry surveys (survey 1995 and data from previous years). Brussels, Geneva and Vienna.

UN/ECE \& EC 1997b. Forest Soil Condition in Europe. Result of a Large-Scale Soil Survey. Brussels and Geneva.

UN/ECE \& EC 1997c. Ten Years of Monitoring Forest Condition in Europe. Brussels and Geneva.

UN/ECE \& EC 2001a. Forest Condition in Europe: Results of the 2000 survey. 2001 Technical Report. Geneva and Brussels.

$\mathrm{UN} / \mathrm{ECE} \&$ EC 2001b. Intensive monitoring of Forest Ecosystems in Europe. Technical Report 2001. Brussels and Geneva. 